\title{
Training for making garden lights with solar energy sources
}

\section{Pelatihan pembuatan lampu taman dengan sumber energi tenaga surya}

\author{
Diana Lestariningsih, Albert Gunadhi, Lanny Agustine, Widya Andyardja \\ Departemen Teknik Elektro, Fakultas Teknik, Universitas Katolik Widya Mandala Surabaya \\ Jl. Kalijudan No. 37 Surabaya, 60114, Indonesia
}

\begin{abstract}
ARTICLE INFO:
Received: 2021-06-07

Revised: 2021-09-05

Accepted: 2021-12-07

Keywords:

Garden lights,

Solarpower, Training,

Curah Cottok

\section{ABSTRACT}

Curah Cottok Village, Kapongan District, Situbondo Regency, East Java has a hill which is an empty and barren land with scorching sun rays from morning until afternoon. The hill was planned by Mr. Muh Samsuri Abbas as the Village Head as a tourist spot. The conditions of the hot area are very suitable for solar power technology applications. To support the realization of tourist spot and take advantage of the scorching weather with sunshine, community service activities were carried out by providing training in making garden lights. To activate the garden lights using solar energy. Garden lights with solar power consist of 5-watt DC lights, 10A BCR, 7AH batteries, 10WP solar panels. There were 32 participants who were divided into 5 groups. Participants were dominated by young adults. The results of the participant's activity are 5 garden lights with solar power that have been installed on the Curah Cottok hill. The garden lights function well by illuminating the top of the Curah Cottok hill at night.

(C) 2022 Abdimas: Jurnal Pengabdian Masyarakat Universitas Merdeka Malang This is an open access article distributed under the CC BY-SA 4.0 license (https://creativecommons.org/licenses/by-sa/4.0/)
\end{abstract}

How to cite: Lestariningsih, D., Gunadhi, A., Agustine, L., \& Andyardja, W. (2021) Training for making garden lights with solar energy sources. Abdimas: Jurnal Pengabdian Masyarakat Universitas Merdeka Malang, 7(1), 64-72.

https://doi.org/10.26905/abdimas.v7i1.5884

\section{PENDAHULUAN}

Desa Curah Cottok, Kecamatan Kapongan, Kabupaten Situbondo, Jawa Timur dengan 565 kepala keluarga mayoritas mata pencahariannya di bidang pertanian (27\% petani dan $40 \%$ buruh tani) (desacurahcottok.blogspot.co.id, 21 Oktober 2017). Dengan demikian, lahan desa mayoritas adalah lahan pertanian. Pengembangan desa yang dilakukan, salah satunya adalah membangun tempat wisata yang mempunyai potensi besar dengan tetap mengedepankan pertanian dan hasil panennya. Untuk menunjang pengembangan tersebut yang dilakukan adalah dengan pengembangan infrastruktur.

Di desa Curah Cottok masih terdapat daerah yang belum terjangkau oleh jaringan PLN, terutama di area persawahan. Jika ingin dikembangkan menjadi kawasan wisata, maka diperlukan alternative sumber energi untuk penerangan kawasan tersebut. Pada saat ini terdapat berbagai jenis energi terbarukan yang dapat dimanfaatkan untuk swasembada energi listrik. Desa Curah Cottok dan sekitarnya rata-rata 
per tahun mengalami 4 bulan musim penghujan. Dengan kondisi curah hujan yang sedikit, maka lahan pertanian cenderung tandus, yang mengakibatkan banyak lahan terbuka, dengan pancaran matahari cukup terik dari pagi hingga menjelang sore hari. Dengan penjelasan kondisi tersebut maka daerah Curah Cottok sangat cocok untuk aplikasi teknologi tenaga surya. Lokasi Bukit Curah Cottok dapat dilihat pada Gambar 1.

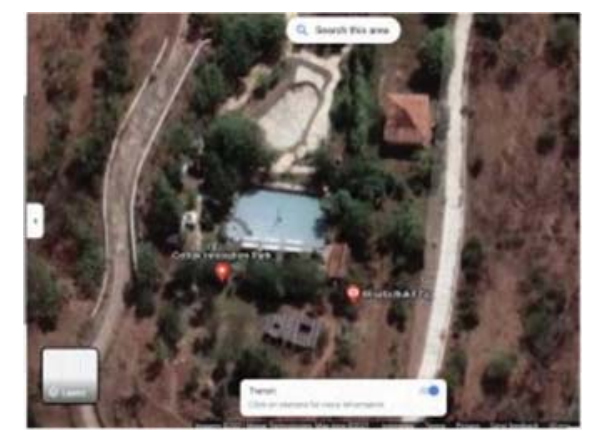

Gambar 1. Peta Lokasi Bukit Curah Cottok

Dari data kondisi daerah Curah Cottok tersebut di atas maka program pengabdian ini bertujuan untuk memberikan pelatihan pembuatan lampu taman dengan menggunakan teknologi tenaga surya bagi kaum dewasa muda di desa Curah Cottok. Lampu taman dipilih untuk mendukung terwujudnya tempat wisata. Lampu taman digunakan untuk menerangi taman pada waktu malam hari. PLTS lebih diutamakan untuk penerangan sehingga untuk keperluan tersebut penggunaan lampu yang memerlukan daya rendah sangat penting sepert Lampu Light Emitting Diode (LED) DC yang hemat energy (Ningsih, 2020).

\section{METODE}

Untuk melaksanakan pengabdian pelatihan pembuatan lampu taman dengan menggunakan teknologi tenaga surya bagi kaum dewasa muda di desa Curah Cottok menggunakan beberapa metode. Dari metode yang dipilih diharapkan dapat mempermudah peserta dalam memahami materi yang disampaikan. Kegiatan pengabdian masyarakat yang dilakukan menggunakan 3 metode yaitu:

\section{Tutorial yang Terbagi Menjadi 3 Materi}

Tutorial dilakukan oleh 2 orang dosen dengan materi pertama adalah pengenalan sistem tenaga surya, dilanjutkan dengan contoh - contoh aplikasi sistem tenaga surya juga kelebihan dan kekurangan sistem tenaga surya serta peralatan yang diperlukan untuk merancang sistem tenaga surya. Bagian utama dari sistem tenaga surya adalah panel surya. Panel surya terdiri dari sel - sel surya atau photovoltaic yaitu perangkat yang mengkonversi radiasi sinar matahari menjadi energi listrik. Sel photovoltaic akan menghasilkan beda potensial berupa tegangan listrik (Usman, 2020). Photovoltaic dapat menghasilkan listrik dari intensitas cahaya matahari, saat intensitas cahaya berkurang (berawan, mendung atau hujan) arus listrik yang dihasilkan juga akan berkurang (Suwarti, 2019). Intensitas cahaya matahari efektif yang dapat dimanfaatkan untuk tenaga surya adalah pada pukul 09.30 WIB sampai 13.30 WIB saat cuaca terang (Tira, 2018).

Beberapa jenis panel surya adalah Monocrystalline Silicon, Polycrystalline Silikon, Thin Film Solar Cell dan Compound Thin Film Triple Junction Photovoltaic. Panel surya monokristalin membutuhkan cahaya yang sangat terang ketika beroperasi dan mengalami pengurangan efisiensi jika berada pada 
ABDIMAS: Jurnal Pengabdian Masyarakat Universitas Merdeka Malang

Volume 7, No 1, February 2022: 64-72

cuaca yang berawan dan mendung. Kinerja Panel monokristalin akan berkurang saat suhu naik atau panas. Kenaikan temperatur dilingkungan disekitar panel surya mengakibatkan tegangan listrik yang diproduksi oleh panel surya menjadi berkurang. Untuk kondisi kota Surabaya, terjadi pengurangan tegangan listrik sebesar $-22 \mathrm{~V} /{ }^{\circ} \mathrm{C}$ saat menggunakan panel surya jenis monokristalin (Suryana, 2016). Panel surya polikristalin lebih tahan panas dibanding monokristal. Efisiensi konversi daya dari tipe monokristalin adalah 11,90 \%, dan tipe polikristalin adalah 9,18 \%. Sedangkan Performance Ratio monokristalin dan polikristalin masing-masing adalah 0,63 dan 0,61 (Asrori \& Yudiyanto, 2019). Untuk jenis thin film solar cell memiliki ukuran yang sangat tipis, memiliki bobot yang lebih ringan dan memiliki sifat yang lebih fleksibel. Selain itu teknologi solar panel jenis thin film berfungsi dengan sangat baik ketika berada pada cahaya fluorescent (lampu pendar). Efisiensi konversi daya cukup rendah sebesar $8,5 \%$ untuk penampang dengan luas yang sama dengan monokristalin. Aplikasi dari thin film solar cell digunakan untuk perangkat elektronik berukuran kecil yang membutuhkan energi tidak terlalu besar seperti kalkulator sel surya, senter sel surya dan jam tangan sel surya. Jenis Compound Thin Film Triple Junction Photovoltaic merupakan teknologi panel surya yang memiliki tiga lapisan jenis panel yang digunakan sebagai perangkat yang ditujukan untuk diterbangkan ke angkasa luar. Jenis panel surya tersebut mampu menghasilkan daya listrik hingga 45\%, memiliki bobot yang sangat berat dan juga sangat rapuh jika dibandingkan dengan teknologi solar panel yang lainnya. Dari penjelasan tersebut panel surya jenis monokristal merupakan pilihan utama dalam efisiensi konversi daya tetapi mengingat di Indonesia memiliki 2 musim yaitu musim hujan dan musim kemarau maka perlu dipertimbangkan penggunaan panel surya jenis polikristalin yang lebih tahan panas dan tetap dapat berfungsi saat suhu naik atau turun.

Pembangkit Listrik Tenaga Surya (PLTS) digolongkan sebagai pembangkit listrik dengan investasi awal yang mahal, oleh sebab itu pemasangan PLTS lebih diutamakan untuk penerangan (Ningsih, 2020). Demikian juga untuk efisiensi dari panel surya, untuk jenis monokristalin dengan rate Maximum Power 50 watt didapatkan hasil efisiensi sebesar $19.5 \%$. Kelebihan dari sistem panel surya adalah potensi energi surya sangat besar tidak terbatas, sekitar rata-rata 4,8 kWh/m2/hari atau setara dengan $112.000 \mathrm{GWp}$ (Meriani, 2017).

Materi ke-2 tentang cara instalasi lampu taman dengan sistem tenaga surya yang didampingi oleh mahasiswa-mahasiswa Jurusan Teknik Elektro. Lampu taman terdiri dari rangka lampu taman, lampu DC 5 watt, BCR 10A, accu 7AH, panel surya $10 \mathrm{Wp}$. Panel surya $10 \mathrm{Wp}$ kinerjanya mampu menangkap sumber energi cahaya buatan dari sebuah lampu Bohlam 100 Watt, yang mengikuti karakteristik sinar matahari. Dari energi cahaya buatan tersebut diperoleh tegangan maksimum 18 Volt DC. Hasil keluaran beban DC tersebut dihasilkan dari aliran baterai $12 \mathrm{~V}$ yang telah terisi 1,25 A, maka mampu menghidupkan lampu DC 12V \& 15W (Assiddiq, 2018).

Energi listrikyang dihasilkan oleh panel surya membutuhkan sebuah alat pengendali yang berfungsi untuk mengatur tegangan dan arus ke baterai, alat pengendali tersebut disebut charge controller atau Battery charge regulator (BCR) dimana fungsi dari alat ini untuk menurunkan tegangan dari panel surya (Astra \& Sidopekso, 2011). Pengisian baterai (charge) dengan sumber Pembangkit Listrik Tenaga Surya dengan kapasitas 12 Volt 10 Ah memakan waktu kurang lebih 5 jam dengan tegangan pengisian 13 Volt dan arus rata-rata pengisian 2.065 ampere (Mahardika et al., 2016)

LED adalah sejenis dioda semikonduktor yang merubah energi listrik menjadi cahaya (Moo et al. 2012). Lampu LED memiliki keunggulan yaitu umur lampu yang lebih panjang dan konsumsi daya yang lebih rendah jika dibandingkan dengan jenis lampu lainnya (Gil-de-Castro et al., 2012; Masoud, 2015). Penggunaan lampu jenis LED akan menggantikan sumber pencahayaan jalan raya yang lama atau lampau, seperti lampu pijar, lampu fluorescent dan lampu sodium bertekanan tinggi (Singh, et al., 2015). 
Untuk perhitungan perancangan lampu taman dengan menggunakan energy panel surya dijelaskan sebagai berikut. Bola lampu taman dengan daya $5 \mathrm{~W}$ diperkirakan menyala aktif selama 12 jam (dari jam 6 sore sampai dengan jam 6 pagi), sehingga daya total yang dibutuhkan adalah 60 watt jam. Tegangan bola lampu 12 volt sehingga besar arus yg dibutuhkan 5 Ampere. Hal ini dibutuhkan untuk memilih Accu yang mendekati besar arus tersebut yaitu $7 \mathrm{AH}$. Selanjutnya menentukan ukuran panel surya. Rata - rata matahari dapat menyinari panel surya selama 8 jam. Daya total lampu yang dibutuhkan 60 watt jam dibagi dengan 8 jam sehingga minimum daya panel surya yang dibutuhkan adalah 7,5 WP (watt peak), sehingga dipilih panel surya yang mempunyai kapasitas 10WP. Hal terakhir yaitu menentukan BCR atau alat pengontrol dengan cara minimum daya panel surya sebesar 7,5 WP dibagi dengan tegangan lampu 12 V hasilnya adalah 0,625 Ampere, sehingga dipilih BCR 10 Ampere (Rezkyanto, 2019)

\section{Evaluasi dengan Melakukan Tes Kompetensi}

Evaluasi dilakukan dengan cara memberi tes kompetensi tentang masing - masing fungsi dan peralatan yang digunakan dalam instalasi sistem tenaga surya. Hasil evaluasi dikoreksi oleh tim dosen dan mahasiswa pendamping. Evaluasi dilakukan untuk meninjau pemahaman peserta dari materi yang telah diberikan sebelumnya.

\section{Studi kasus dalam kelompok untuk instalasi sistem penerangan lampu taman}

Studi kasus dalam kelompok dilakukan dengan memberikan semua peralatan yang dibutuhkan dalam instalasi lampu taman yaitu 1 set tool kit, kabel, solder, timah, rangka lampu taman, lampu DC 5 watt, BCR 10A, accu 7AH, solar panel 10WP. Untuk efektifitas kegiatan maka jumlah peserta sebanyak 30 orang dibagi dalam 5 kelompok. Gambar peralatan yang digunakan dapat dilihat pada Gambar 1.
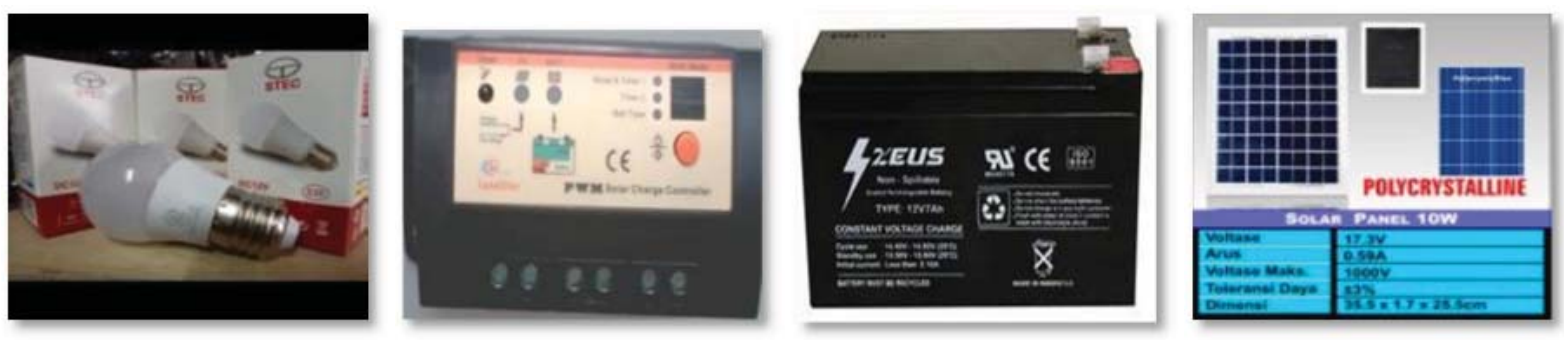

Gambar 2. Lampu DC 5 watt, BCR 10A, Accu 7AH dan Panel Surya 10WP

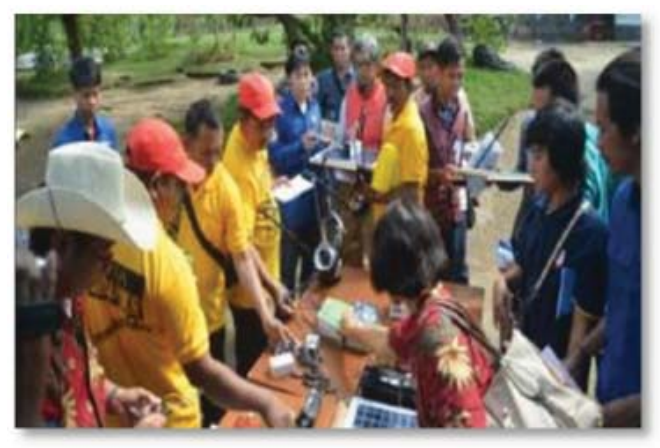

Gambar 3. Pembagian tool kit, kerangka lampu hias dan Set Tenaga Surya 
ABDIMAS: Jurnal Pengabdian Masyarakat Universitas Merdeka Malang

Volume 7, No 1, February 2022: 64-72

Gambar 2 memperlihatkan pembagian tool kit, kerangka lampu hias dan 1 set peralatan yang dibutuhkan untuk instalasi tenaga surya.

\section{HASIL DAN PEMBAHASAN}

Hasil

Kegiatan pengabdian masyarakat dengan tema: Pelatihan Pembuatan Lampu Taman dengan Sumber Energi Tenaga Surya telah dilaksanakan pada tanggal 1-3 Desember 2017, di area rumah Kepala Desa Curah Cottok, Kecamatan. Kapongan, Kabupaten. Situbondo. Tim terdiri dari 4 orang dosen Jurusan Teknik Elektro (JTE) dibantu 5 orang mahasiswa JTE untuk mendukung kegiatan praktis. Total peserta yang hadir sejumlah 32 orang yang berasal dari 3 desa berdekatan. Peserta didominasi kaum pria, baik muda maupun tua yang sedang mendengarkan penjelasan dari pemateri pertama yaitu pak Widya diperlihatkan pada Gambar 3.
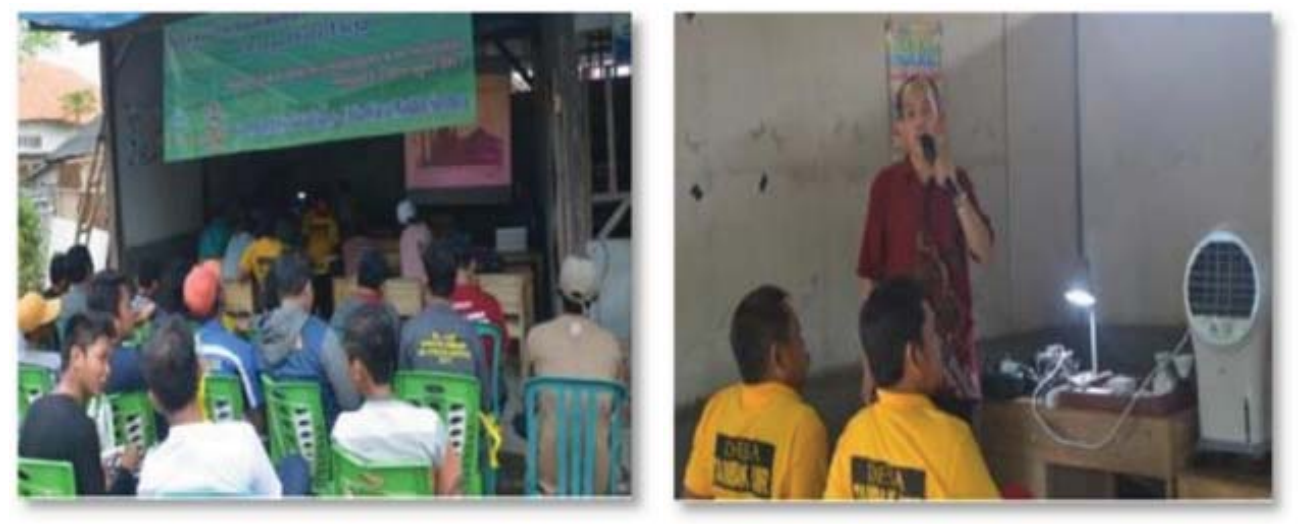

Gambar 4. Peserta didominasi oleh kaum Pria

\section{Tahapan pelaksanaan}

\section{Presentasi}

Minat masyarakat untuk mengikuti pelatihan cukup tinggi dengan dukungan pimpinan desa yang memberikan dukungan penuh pada kegiatan tersebut. Kegiatan diawali dengan pemaparan materi untuk pengenalan sistem tenaga surya oleh Pak Widya. Pada saat presentasi ini juga diberikan gambaran contoh penerapan panel surya. Hal ini dimaksudkan untuk mempermudah pemahaman peserta untuk penggunaan panel surya dalam kehidupan sehari - hari.

\section{Evaluasi tes pemahaman materi}

Setelah selesai pemaparan materi, dilanjutkan dengan evaluasi yang dilakukan dengan memberi soal pilihan ganda untuk meninjau pemahaman materi yang telah diberikan sebelumnya. Gambar 4 memperlihatkan peserta sedang mengerjakan evaluasi tes pemahaman materi dan tim dosen juga mahasiswa saat memeriksa berkas jawaban dari peserta. Selama evaluasi berlangsung, peserta boleh melihat materi dalam modul yang telah dibagikan sebelumnya ke setiap peserta. Peserta juga diperbolehkan untuk bertanya apabila kurang memahami pertanyaan yang tercantum dalam lembar evaluasi. 

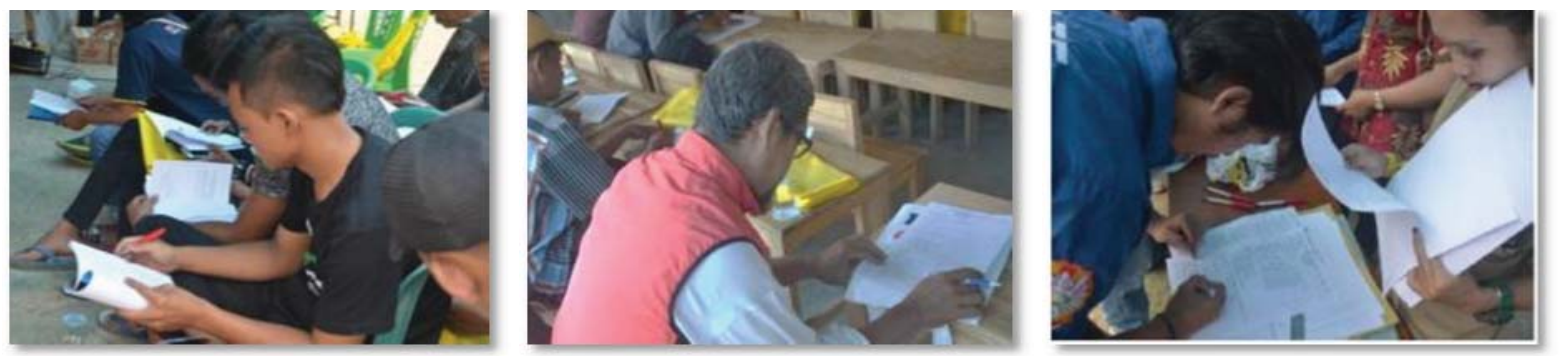

Gambar 4. Evaluasi Peserta Abdimas dengan Tes Kompetensi

Berkas jawaban dari peserta dikumpulkan dan diberi nilai oleh tim dosen dan mahasiswa pendamping selama pelatihan berlangsung. Tiga peserta yang mendapatkan nilai terbaik mendapatkan souvenir yang sudah dipersiapkan oleh tim.

\section{Studi kasus instalasi sistem penerangan lampu taman}

Acara yang dilakukan selanjutnya adalah studi kasus dalam kelompok untuk instalasi sistem penerangan lampu taman. Kegiatan praktis berjalan dengan efektif dengan cara dibagi menjadi 5 kelompok, dan tiap kelompok didampingi oleh dosen dan mahasiswa. Dalam studi kasus instalasi juga dilakukan pengambilan nilai kelompok dengan target waktu tercepat untuk menyelesaikan proses instalasi hingga pengujian sistem penerangan lampu taman. Hasil instalasi tiap kelompok dapat dikatakan berfungsi dengan baik jika dapat menunjukkan lampu taman akan menyala aktif saat tidak terdapat sinar matahari dengan cara panel surya ditutup dengan kain dan lampu taman akan mati saat sensor terkena cahaya matahari. Kelompok dengan instalasi yang benar dan tercepat mendapat souvenir dari tim dosen. Gambar 5 memperlihatkan tiap - tiap kelompok saat melakukan instalasi dan pengujian fungsi lampu taman.
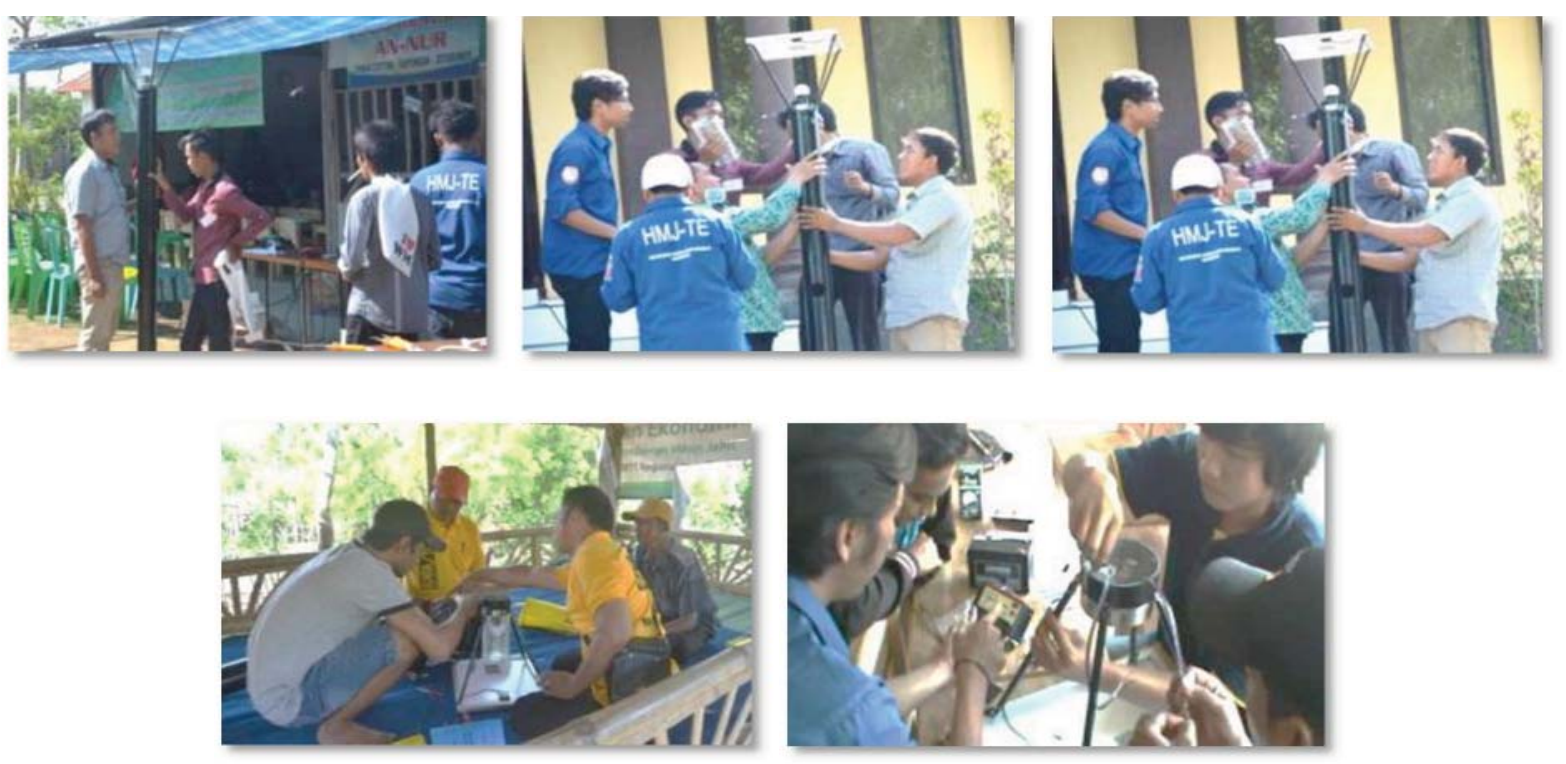

Gambar 5. Peserta Beraktifitas Dalam Kelompok

Dibantu Mahasiswa Pendamping Merakit dan Instalasi Lampu Taman (kelompok 1, 2, 3, 4, 5) 
ABDIMAS: Jurnal Pengabdian Masyarakat Universitas Merdeka Malang

Volume 7, No 1, February 2022: 64-72

Lima set sistem lampu taman dari hasil aktifitas kelompok tersebut kemudian diangkut dengan menggunakan berbagai kendaraan milik peserta menuju puncak bukit Curah Cottok dengan diikuti peserta dan mahasiswa serta dosen pendamping. Di puncak bukit, peserta bersama - sama memasang sistem lampu taman pada 5 titik yang telah dipersiapkan oleh pihak desa. Pengujian akhir dilakukan kembali dilakukan di bukit Curah Cottok untuk memastikan bahwa sistem lampu taman tetap berfungsi dengan baik. Gambar 6 memperlihatkan hasil pengujian lampu taman, pengangkutan lampu taman menuju ke bukit Curah Cottok dan pemasangan lampu taman di bukit Curah Cottok.
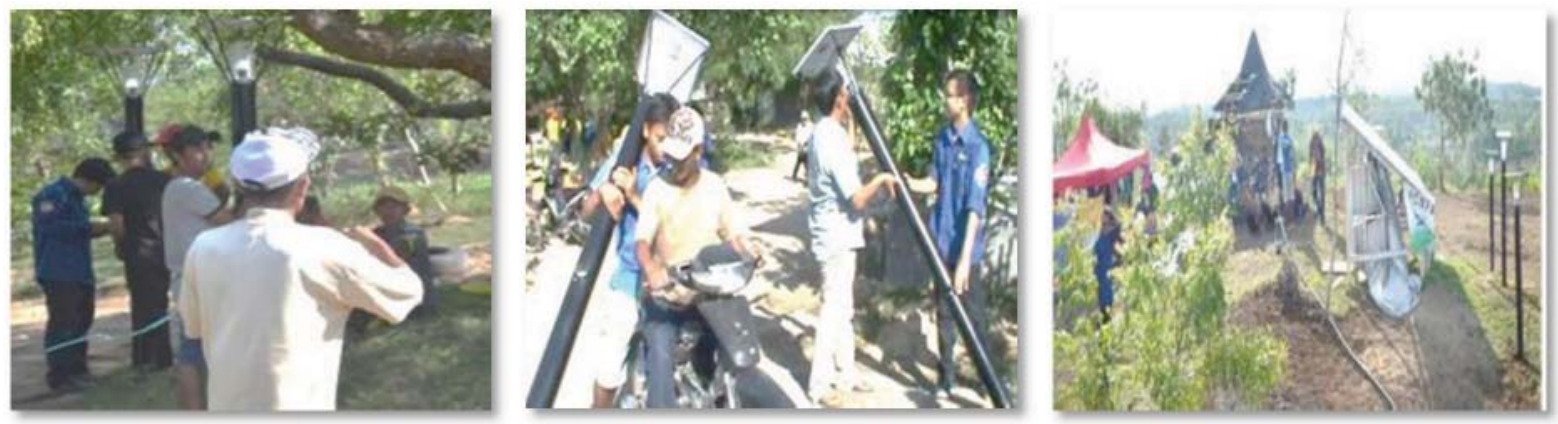

Gambar 6. Hasil pengujian lampu taman, pengangkutan lampu taman menuju ke bukit Curah Cottok dan pemasangan lampu taman

Pemasangan lampu taman di bukit Curah Cottok ditempatkan pada titik - titik yang sudah disiapkan terlebih dahulu oleh ketua tim karang taruna. Pemasangan dilakukan mandiri oleh peserta tiap kelompok. Kegiatan selanjutnya adalah melakukan dokumentasi pengambilan foto bersama di bukit Curah Cottok. Selanjutnya seluruh peserta dan tim pendamping turun dari bukit untuk kembali ke tempat pertemuan. Acara ditutup dengan kesan-kesan dari wakil peserta dan penyerahan sertifikat bagi peserta secara simbolis. Pak Joedo sebagai penggiat kemajuan desa mewakili pihak Desa Curah Cottok dan Ir. Rasional Sitepu sebagai wakil senior dari tim abdimas JTE UKWMS memberikan sambutan penutup. Dengan antusiasme dari para peserta dan pihak pimpinan desa, maka direncanakan kegiatan akan terus dikembangkan untuk mendukung rencana desa Curah Cottok dalam merealisasikan masyarakat yang berkompetensi teknologi.

\section{Pembahasan}

Pemaparan pengenalan materi sistem tenaga surya dilakukan selama 1 jam. Waktu yang dialokasikan cukup singkat untuk mengalokasikan sesi selanjutnya yang membutuhkan waktu yang lebih lama yaitu instalasi sistem penerangan tenaga surya dan pemasangannya di bukit Curah Cottok. Peserta tidak mengalami kesulitan dalam memahami materi pengenalan sistem tenaga surya, tetapi kesulitan tersebut muncul pada saat peserta harus memperhitungkan arus, tegangan, lama penggunaan beban lampu yang dibutuhkan untuk menentukan besaran Accu dan BCR yang akan digunakan. Hal ini terjadi karena usia peserta yang bervariasi dari kalangan muda sampai tua dan hamper sebagian peserta tidak mempunyai dasar ilmu kelistrikan. Kendala tersebut akan diatasi dengan cara pelatihan sistem tenaga surya yang direncanakan berkelanjutan seiring dengan rencana pembangunan tempat wisata di bukit Curah Cottok.

Materi selanjutnya adalah evaluasi dilakukan selama 30 menit. Dari hasil evaluasi terdapat beberapa peserta menguasai materi tenaga surya dan sebagian besar membutuhkan materi lebih lanjut tentang dasar kelistrikan dan terutama untuk memahami perhitungan sistem tenaga surya. 
Untuk materi instalasi lampu taman, didalam pelaksaannya, mahasiswa menerangkan sekilas rangka lampu taman yang harus disusun dan beberapa saat kelompok mengerjakan secara mandiri instalasi yang harus dilakukan. Pada saat kelompok mengalami kesulitan, paramahasiswa akan memberikan arahan penyelesaian masalah. Waktu yang dibutuhkan untuk perakitan dan instalasi membutuhkan waktu yang lama, karena peserta membutuhkan penyesuaian dalam mengenali kerangka lampu taman dan cara perakitan. Demikian juga dengan instalasi lampu taman dengan tenaga Surya, peserta diajarkan kebiasaan baru untuk selalu memantau keadaan arus dan tegangan yang terbaca di BCR.

\section{SIMPULAN DAN SARAN}

Berdasarkan uraian dari hasil dan pembahasan sebelumnya maka selama pengabdian masyarakat dapat diambil kesimpulan bahwa efisiensi kegiatan pengabdian pada masyarakat dihadiri oleh 32 orang. Untuk efektifitas kegiatan mencapai $80 \%$, diukur dari keberhasilan peserta menyelesaikan tugas praktis yang diberikan, semua peserta aktif terlibat dalam kegiatan. Lima lampu taman berhasil diinstalasi oleh peserta dan berfungsi dengan baik yaitu pada saat terdapat sinar matahari lampu taman akan mati dan akan menyala pada saat tidak terdapat sinar matahari. Lima lampu taman berhasil ditanam di bukit Curah Cottok.

Bukit Curah Cottok yang akan dijadikan tempat wisata masih sangat terbuka untuk dilakukan pengembangan dan pembangunan. Bapak Samsuri sebagai Lurah Curah Cottok juga sangat terbuka bagi institusi yang bersedia untuk menyumbangkan pikiran dan keahlian untuk terwujudnya wisata bukit Curah Cottok. Bagi tim JTE juga direncanakan secara berkelanjutan melakukan pengabdian masyarakat untuk membantu terwujudnya tempat wisata di bukit Curah Cottok.

\section{DAFTAR PUSTAKA}

Asrori, A., \& Yudiyanto, E. (2019). Kajian karakteristik temperatur permukaan panel terhadap performansi instalasi panel surya tipe mono dan polikristal. FLYWHEEL/ : Jurnal Teknik Mesin Untirta, 1(1), 68. https://doi.org/10.36055/fwl.v1i1.7134

Assiddiq, H. (2018). Studi pemanfaatan energi matahari sebagai sumber energi alternatif terbarukan berbasis sel fotovoltaik untuk mengatasi kebutuhan listrik rumah sederhana di daerah terpencil. Al-Jazari Jurnal Ilmiah Teknik Mesin, 3(2). https://doi.org/10.31602/al-jazari.v3i2.1624

Astra, I. M., \& Sidopekso, S (2011). Studi rancang bangun solar charge controller dengan indikator arus, tegangan dan suhu berbasis mikrokontroler ATMEGA 8535. Jurnal Spektra: Fisika dan Aplikasinya, XI(1).

Gil-de-Castro, A., Moreno-Munoz, A., Larsson, A., de la Rosa, J., \& Bollen, M. (2012). LED street lighting: A power quality comparison among street light technologies. Lighting Research \& Technology, 45(6), 710-728. https://doi.org/10.1177/1477153512450866

Mahardika A., Wijaya A., \& Rinas I W. (2016). Rancang bangun baterai charge control untuk sistem pengangkat air berbasis arduino uno memanfaatkan sumber PLTS. SPEKTRUM, 1(1)

Masoud, M. I. (2015). Street lighting using solar powered LED light technology: Sultan Qaboos University case study. 2015 IEEE 8th GCC conference \& exhibition. https://doi.org/10.1109/ieeegcc.2015.7060015

Meriani, M. (2017). Kajian potensi dan efisiensi energi Pembangkit Listrik Tenaga Surya (PLTS) di wilayah Pekanbaru. Jurnal Surya Teknika, 5(01), 19-25. https://doi.org/10.37859/jst.v5i01.352 
ABDIMAS: Jurnal Pengabdian Masyarakat Universitas Merdeka Malang Volume 7, No 1, February 2022: 64-72

Moo, C. S., Chen, Y. J. \& Yang, W. C, (2012). An efficient driver for dimmable LED lighting. IEEE Trans. Power Electron. 27, 4613-4618.

Ningsih, P. S. (2020). Pengukuran tegangan, arus, daya pada prototype PLTS berbasis mikrokontroller Arduin Uno. SainETIn, 5(1), 8-16. https://doi.org/10.31849/sainetin.v5i1.4370

Rezkyanto, R., A, (2019). Penentuan kapasitas sel surya dan baterai terhadap karakteristik beban listrik. Doctoral Dissertation. Universitas Muhammadiyah Surakarta.

Singh, D., Basu, C., Meinhardt-Wollweber, M., \& Roth, B. (2015). LEDs for energy efficient greenhouse lighting. Renewable and Sustainable Energy Reviews, 49, 139-147.

https://doi.org/10.1016/j.rser.2015.04.117

Suwarti. (2019). Analisis pengaruh intensitas matahari, suhu permukaan \& sudut pengarah terhadap kinerja panel surya. Eksergi, 14(3), 78. https://doi.org/10.32497/eksergi.v14i3.1373

Suryana, D. (2016). Pengaruh temperatur/suhu terhadap tegangan yang dihasilkan panel surya jenis monokristalin (studi kasus: Baristand Industri Surabaya). Jurnal Teknologi Proses Dan Inovasi Industri, 1(2). https://doi.org/10.36048/jtpii.v1i2.1791

Tira, H. S. (2018). Pengaruh sudut surya terhadap daya keluaran sel surya 10 wp tipe polycristalline. Jurnal Teknik Mesin, 7(2), 69. https://doi.org/10.22441/jtm.v7i2.2676

Usman, M. (2020). Analisis intensitas cahaya terhadap energi listrik yang dihasilkan panel surya.power elektronik. Jurnal Orang Elektro, 9(2), 52-57. https://doi.org/10.30591/polektro.v9i2.2047 